\section{SEX EDUCATION: AIMS, POSSIBILITIES AND PLANS*}

\section{By CYRIL BIBBY}

$I^{\mathrm{T}}$ is sometimes forgotten by many educationists to-day how much is owed to the pioneers in the field of sex education. Whatever differences of opinion there may be about the desirability of the specific measures they recommended, it is clear that the great advance in sex education which is taking place to-day could not have occurred if they had not prepared the ground. As a result of their work, views that were novel and unorthodox are now almost commonplace and acceptable even in official circles.

Perhaps the greatest turning point on this path towards official recognition was the transference in 1942 of the major part of the work of the British Social Hygiene Council to the Central Council for Health Education. What this official support has meant to the cause of sex education is perhaps best illustrated by some figures. The numbers of sex education lectures given by these two bodies to certain types of audience during the past five years are as follows:

$\begin{array}{lccccc}\text { AUDIENCE } & 1940-41 & 1941-42 & 1942-43 & 1943-44 & 1944-45 \\ \text { Teachers } & 7 & 95 & 83 & 86 & 232 \\ \text { Youth leaders } & 17 & 35 & 33 & 59 & 118 \\ \text { Parents } & 21 & 39 & 37 & 75 & 117 \\ \text { Young people } & 257 & 612 & 580 & 1,348 & 1,416 \\ \text { School children } & 71 & 87 & 101 & 208 & 159\end{array}$

The total attendance at these meetings during 1943-44 was 68,712 (the figures for 1944-45 being not yet available) while, if the audiences at meetings and film shows on venereal diseases are included, the total attendance during the year was some 300,000 . Quantitatively, then, the present position is fairly satisfactory. The number of people who have received some sort of sex education during the last five years is considerable.

It is clear that there has been of recent years a radical and widespread change of public opinion on the question of sex education. The time has passed when it was necessary to state with some vehemence the case against sheer obscurantism. Probably there will remain with us for many years a few frightened adults who will continue to foster the cult of ignorance; but an increasingly large section of the population is allowing the myths of the gooseberry bush and the stork to fade into oblivion. The general public, educational and medical administrators, churches and social organizations, teachers and youth leaders, parents and pupils - all are ready to go ahead. No longer is it necessary to press the claims of sex education in language more vigorous than profound. Now is the need for careful study of the many educational issues involved. Only after such study is it likely that the position in sex education will be at all satisfactory as regards quality.

The first issue for study is that of objective. What are the aims of sex education and what are its possibilities? To serve as a basis for useful action, an objective must be desirable, attainable and sufficient - and this cannot be said of some aims that have been propounded.

There are, for example, those who use 'sex education' as an euphemism for dilation on the horrors of

* Substance of an address at the annual general meeting of the Eugenics Society on May 29. The paper will be published in full in the Eugenics Review. venereal disease, and hope to frighten young people into 'goodness'. But sex education is not mere antivenereal propaganda; it is preparation to live a joyous, well-balanced and fruitful life. There are others whose aim is to produce 'morality' by threats of fire and brimstone. But the educationist can have no concern with such 'goodness' and such 'morality'. Such aims fail on the test of desirability.

Other aims, perhaps desirable enough in themselves, fail on the score of feasibility. To expect by sex education alone to wipe out prostitution and casual promiscuity, to make all marriages successful and all divorces disappear, to abolish adultery and prevent all formication, is to be hopelessly unrealistic. Many and deep seated are the sexual ills of society, and education unaided will not eradicate them. Economic and political changes and a new social and spiritual vision are needed too.

Now what of the criterion of sufficiency ? A great many people seem to imagine that sex education consists merely of imparting the so-called 'facts of life', although one would have thought that the inadequacy of this conception were sufficiently clear. A study of ancient or contemporary history, or even a superficial knowledge of the lives of one's acquaintances, will rapidly dispel any illusion that there is necessarily a close correlation between the extent of an individual's biological knowledge and the excellence of his actions.

The teaching of the obvious biological facts will make it clear to our children that the human sex organs are essentially similar to those of other mammals, such as the rabbit; and if sex education were to stop there, it would be logical for a child to deduce that the sexual behaviour of a healthy young human should not be very different from that of a healthy young rabbit. But since presumably we do not wish to adopt the rabbit as the model for our sexual behaviour, sex education must at the appropriate stages deal also with those respects in which humans differ from the other mammals, and in particular with the consequences of the unique development of our nervous system and of our peculiar sociability.

But still something else is needed. Our children must be inspired with a feeling of the excellence of sex and of its immense potentialities. Our young people, if they are to deny themselves the immediate sensual pleasures with which our bodies can so richly provide us, must see some reason for such a sacrifice. If they are to be asked to wait, they must feel that they have a future, and a future that is worth waiting for. If society is to make demands, it must see to it that its members think sufficiently highly of it to be willing to accede to them. Behaviour is dependent upon ideals and inspiration, as well as upon factual knowledge and intellectual understanding.

It is, however, easy enough to criticize aims expounded or implied by others. Much more difficult is the task of formulating a statement to take their place. I do not feel sufficiently confident to do so at all dogmatically; but at any rate a tentative effort should be made. I would, therefore, define the aims of sex education something along these lines: "That our people should grow up learning the appropriate facts in the best possible way; that their general attitude to sex should be a completely healthy one; that they should draw up for themselves a code of conduct after careful consideration. of all the issues involved and should endeavour to behave according to this rationally determined code; and that they 
should react to the behaviour of others with sympathy, tolerance and charity, but without spineless acquiescence in a code inferior to their own." No doubt this statement of aims could be much improved, but it will serve as a working basis for the time being.

First, what constitutes 'appropriate' knowledge and at what age should it be imparted? This latter query is clearly one to which there is no simple answer. No one age can be prescribed for sex education, any more than it can for any other aspect of health education or character training. Sex educa. tion should surely be a continuous process from early years to later life, and the question should really be re-phrased to read: What aspects of sex education are particularly appropriate to different ages ? This is obviously difficult to answer in general terms, for no one human is exactly like another; but if we call to our aid that mythical creature the 'average' person, a reply may be attempted.

I would suggest that by about the age of two or three years, children should be learning the polite terminology for the sex organs, just as they learn the words 'arm', 'leg', and 'head'. By the time they go to school at about five, they should in most cases know that the baby grows inside the mother and is born via an opening between her legs; and should understand something of the similarities between birth in humens and in the domestic manmals. During the next two or three years the child should learn that the father contributes the sperm cell which fertilizes the mother's egg, and that the penis is placed in the vagina during mating.

These apparently dogmatic statements about the order in which information should be imparted are not made without reason. The suggested order is that indicated by analysis of the questions typically asked by children of various ages. Questions about birth and pregnancy tend to be asked first of all. It is usually only later that the child inquires about the role of the father, and thus elicits explanations of fertilization and copulation. My belief is that, in general, the right time for enlightenment is when the child seeks it - not when some adult thinks that an appropriate age has been reached.

There are some things, however, in which the adult must act as pacemaker, because the adult knows what sort of ground lies ahead and the child does not. Some time from about the age of twelve onwards a girl will begin her menses, and she needs to be prepared in advance by a simple biological explanation at the age of about eleven. Boys also should have an idea of the significance of menstruation, so that they do not build up on a basis of ignorance an atmosphere of mystery about their sister's periods. But more important for boys is a preparation for the changes that will occur in themselves during adolescence, and in particular for the onset of seminal emissions which, accompanied as they often are by erotic dreams, cause adolescent boys a good deal of needless worry. Minds worried and-terrified by the outrageous allegations which still circulate about the alleged ill-effects of masturbation need also to be set at rest - or, better still, so fortified by the truth that the worries and fears never materialize.

So far no mention has been made of any other than the reproductive aspect of sex, and there is, I believe, good reason for this. It is clear from their whole attitude that most children of less than about twelve years (or even older) think of sex as a purely reproductive matter, and have no conception of its amatory aspect. During the three or four succeeding years, however, the endocrine changes of adolescence begin to produce deeper sexual feelings; an understanding of the love aspect of sex begins to dawn and, with it, an interest in the morals and social conventions of sexual behaviour. This, therefore, I suggest is the period when a point should be made of explaining something more of the influence of the endocrine secretions on the body and the emotions. This, too, is probably the best time for discussing questions such as courtship and marriage, 'necking and petting', promiscuity and prostitution; and for imparting the elementary facts about the venereal disenses.

Towards the end of adolescence and in early adult life, general sex education merges into specific marriage preparation and guidance - a topic too large to consider in any detail now. It may be suggested, however, that apart from a knowledge of the actual technique of intercourse, sex education during the courtship stage should emphasize the importance of each partner understanding well the emotional peculiarities of the other and exercising delicacy and restraint in whatever degree of love-making may be mutually agreed upon. Couples contemplating marriage should be encouraged to learn gomething of each other's physical and mental health ; to understand the economic implications of marriage and parenthood; to reach agreement on how their future home is to be run; and they should be informed of the sources to which they can turn for further information and guidance.

Sex education, however, should not end with marriage. Apart from any continuing guidance in the technique of intercourse, I believe that all married couples should have some training in child eare and parenteraft and - of particular relevance here $\rightarrow$ should be given some understending of the normal sexual development of children and of how to cope with the problems arising from it. Here, however, the sex education of one generation merges into that of the next; and perhaps we had better leave the matter for the time being.

The next problem is that of the encouragement of a healthy attitude to sex, and this is a difficult matterpartly because there is by no means unanimity about what in fact constitutes a healthy attitude. I can do no more, therefore, than register my own personal credo.

It seems clear that on impressions gained and attitudes formod in the first five years of life depend to a considerable extent the emotional balence and happiness of the adult. Let us, therefore, examine some of the factors influencing these impressions and attitudes, Because of the elose physical proximity and nervous connexion between the voiding and the genital orgens, attitudes developed with reference to the former are likely to be transferred to the latter. Any feeling of distaste for the process or the products of voiding may, therefore, have a decidedly unfortunate influence on later feelings about sex. Thus it is patently important not to encourage such feelings; but on the contrary to convey the impression that voiding, like eating, is a perfectly normal and proper process.

Then there is the question of the so-oalled 'infantile masturbation'. It is unfortunately the that many parents, mistaking the exploratory path of innocence for the broad highway of incipient vice, either tell the child not to be 'nasty' or 'rude', or by some action show their disapproval. What is the poor infent to think, that it may safely pull its 
nose and may twiddle its toes with impunity; but if it does the same in a region half-way between, it incurs displeasure? Clearly there is nothing better calculated to encourage the feeling from the earliest days, that there is something quite isolated from the rest of life, something unclean, about the sexual organs, and hence at a later date by association, about the sexual functions. This too, therefore, must be avoided.

Now, what of the question of nudity? It is a commonplace that attitudes to sex are often associated with similar attitudes towards nudity, so if a child from the first learns to regard nudity as in no way an indecent phenomenon, it is reasonable to hope that it will be helped in the development of a healthy attitude to sex. Naturally, however, children must, to save both themselves and others from embarrassment, learn as they grow up that there are occasions and places, including most public occasions and public places, in which nudity is frowned upon.

A great opportunity for encouraging a proper attitude to sex occurs when another child is expected in the family. By careful preparation on the part of the parents, a sense of pleasurable anticipation may be aroused in the children and erowned with a feeling of family solidarity when the baby arrives, and that surely is the goal to aim at.

During these early years, moreover, there are certain attitudes not specifically sexual in nature which are, nevertheless, of fundamental importance in laying the foundations for a successful family life in later years. I have in mind the development of habitual friendliness to the other members of the family, of affection and consideration for others, of willingness to share possessions and to co-operate amicably in activities with playmates. I have in mind also the growth of interest in, and of a sense of wonder at, the workings of Nature, the growth of an æsthetic sense, of a desire for personal health and cleanliness, of admiration for vigour and smartness, of distaste for furtiveness and dishonesty. Sex education, indeed, interpenetrates indissolubly with general character training.

With the onset of adolescence other more specifically sexual attitudes become important. One should endeavour to arouse a sense of pride in approaching maturity. It is important also that each sex should develop an attitude of sympathetic consideration to the other, regarding friendships as perfectly natural and quite desirable, but as needing the exercise of discretion and restraint. This is the period too, I suggest, when one should particularly endeavour to encourage an attitude of distaste for obscenity and pornography-without, however, going to the other extreme of prudery or priggishness. There are those, I know, who believe that sex is so sacred that it should never be the object of humour. For my part, I do feel that certain aspects of sex and sex behaviour are sometimes rather ludicrous, that sex may sometimes quite properly be the occasion of humour; and I would therefore emphasize the importance of avoiding the sin of hypocrisy. The distinction to make is surely that between hearty, unashamed laughter and nasty, shamefaced sniggering; between something which is funny and incidentally sexual and something which is merely filthy in nature.

By the time adult life is reached, basic attitudes are already largely determined. It is important, however, if the idea of sex education is to be widened, as I believe it should be, into a conception of education for family life, that we should devote attention to encour- aging those contemplating marriage to be willing to discuss reasonably and in a friendly spirit, such matters as the economic running of the home, the division of domestic duties, family planning and so on; and that we should endeavour to ensure that married persons should be considerate in all things towards the spouse, should not regard the wedding ceremony as terminating the period of courtship; should have a proper attitude to the upbringing of their offspring. But once again we have made the circle, and have reached to the next generation.

( $T$ o be continued.)

\section{OBITUARIES}

\section{Mr. W. Sydney Smith, C.B., O.B.E.}

Wrlliam Sydney SMrth was a native of Nottingham. He was born in 1866, the eldest son of Samuel Smith, of the firm of Sydney Smith and Sons, engineers. Educated at Nottingham High School, where he excelled in class and in sports, at the age of sixteen he was apprenticed to a Nottingham engineering firm. During his apprenticeship, while working from 6 a.m. to 5.30 p.m., he attended evening classes, an early indication of his grit and determination. He first intended to take up teaching, but winning in 1889 a Whitworth Exhibition of $£ 100$, he decided to follow the family tradition of engineering, and taking his B.Sc. (London) degree, in 1890, he joined his father in his engineering business for a short time. He then went to an electrical engineering firm at Westminster, and on, for a while, to Willans and Robinson at Thames Ditton, returning to his father's firm in 1893 .

On the death of his father in 1895, Sydney Smith sat for a Home Office examination and was appointed one of H.M. inspectors of factories, going to Manchester in 1896 and from there in 1905 to Derby. While in Manchester he compiled a 'blue book' on hoists and lifts. In 1908 he was appointed H.M. inspector of dangerous trades at the Home Office.

Early in 1918 the late Sir Henry Fowler, who had known Sydney Smith at Derby and had a high opinion of his personal qualities and his engineering ability, recommended him as his successor as chief superintendent of the Royal Aircraft Establishment at Farnborough, Hants, and he served there until his retiremont in 1928 .

Though having little aeronautical experience, Sydney Smith quickly grasped the essentials of the work of the Establishment, and he keenly encouraged all steps to improve its effectiveness as the main centre of aeronautical research, and to make its resources, and the results of its work, readily available to the aircraft industry. The period of his work at the Royal Aircraft Establishment was not an easy one; after the change from a war economy to that of peace, the further retrenchment in Government expenditure necessitated the discharge of a large number of the employees. He was a great friend of the staff and workpeople, to whom he was endeared by his obyious integrity, his strict fairness to all and his sympathy and consideration for their welfare; and it was very painful to him to have to discharge men at a time when employment was not easy to obtain.

His work at the Royal Aircraft Establishment was recognized by the award of the O.B.E. in 1918 and C.B. in 1922 .

Sydney Smith had a great habit of early rising, and 